\title{
Population, ecology and morphology of Saga pedo (Orthoptera: Tettigoniidae) at the northern limit of its distribution
}

\author{
ANTON KRIŠTíN and Peter KAŇUCH \\ Institute of Forest Ecology, Slovak Academy of Sciences, Štúrova 2, 96053 Zvolen, Slovakia; e-mail: kristin@savzv.sk
}

Key words. Tettigoniidae, survival strategies, endangered species, large insect predators, ecological limits

\begin{abstract}
The bush-cricket Saga pedo, one of the largest predatory insects, has a scattered distribution across 20 countries in Europe. At the northern boundary of its distribution, this species is most commonly found in Slovakia and Hungary. In Slovakia in 2003-2006, 36 known and potentially favourable localities were visited and at seven this species was recorded for the first time. This species has been found in Slovakia in xerothermic forest steppes and limestone grikes ( $98 \%$ of localities) and on slopes $\left(10-45^{\circ}\right)$ with south-westerly or westerly aspects $(90 \%)$ at altitudes of $220-585 \mathrm{~m}$ a.s.l. (mean $433 \mathrm{~m}, \mathrm{n}=20$ localities). Most individuals $(66 \%)$ were found in grass-herb layers $10-30 \mathrm{~cm}$ high and almost $87 \%$ within $10 \mathrm{~m}$ of a forest edge (oak, beech and hornbeam being prevalent). The maximum density was 12 nymphs $\left(3^{\text {rd }}-5^{\text {th }}\right.$ instar $) / 1000 \mathrm{~m}^{2}$ (July $4,510 \mathrm{~m}$ a.s.l.). In a comparison of five present and previous $S$. pedo localities, 43 species of Orthoptera were found in the present and 37 in previous localities. The mean numbers and relative abundance of species in present $S$. pedo localities were also significantly higher. $S$. pedo individuals at the northern boundary of their distribution were expected to be smaller and lighter because of suboptimal ecological conditions there. However, the body size of S. pedo individuals from these areas were similar to the average value for the whole area. Based on analyses of present and former localities and the Orthopteran assemblages around $S$. pedo, the factors endangering this species, and methods for conserving it and its habitat are discussed.
\end{abstract}

\section{INTRODUCTION}

The long-term future of large predators, including insects, is frequently connected with the increased threat to the survival of individuals or populations. These species are usually at the top of trophic pyramids and their abundance limited by the availability of suitable prey and well-preserved, natural or semi-natural habitats. The species Saga pedo (Pallas, 1771) historically occurred in 20 countries in Europe. It is distributed from Portugal in the west, to western Siberia in the east and Sicily in the south - its northern boundary runs across the Czech Republic and Slovakia (Heller et al., 1998; Heller, 2004). Furthermore, the species was introduced into North America before 1970 (Cantrall, 1972). In Central Europe, at the northern boundary of its distribution, the species is most commonly found in Hungary (ca 80 localities, Nagy et al., 1984; Oláh, 1987; Kenyeres et al., 2002), Slovakia (Vidlička et al., 2002; Krištín et al., 2005; Krištín \& Kaňuch, 2006), rarely in Austria (Berg \& Zuna-Kratky, 1997) and sporadically in the Czech Republic (Kočárek et al., 2005).

This species can reach a body length, including the ovipositor, of up to $105 \mathrm{~mm}$, and it is one of Europe's largest insects (Kaltenbach, 1967). The species is xerothermophilous and pratinicolous, with a Pontomediterranean distribution of paleogeic origin; in Europe it is critically endangered (Nagy et al., 1984; Fontana \& Cussigh, 1996; Willemse, 1996; Berg \& Zuna-Kratky, 1997; Ingrisch \& Köhler, 1998; Krištín, 2001; Kenyeres et al., 2002). It is obligatorily parthenogenetic, and no males have been recorded (Kaltenbach, 1967, 1970; Harz, 1969). The ecology of this non-flying endangered insect has been documented in different areas and habitats, but the data is mostly older than 30-40 years (Werner, 1905; Jaus, 1934; Nagy, 1960; Kaltenbach, 1970; Nagy et al., 1984; Oláh, 1987; Fontana \& Cussigh, 1996). Taxonomical and morphological aspects of the genus Saga in Europe were evaluated by Kaltenbach $(1967,1990)$, and the life history and morphology of $S$. pedo by Schall (2002). However, it is not clear whether the individuals of northern populations differ in body size from those in southern populations. On the other hand, it is well known that $S$. pedo is endangered (Willemse, 1996), certainly by insecticides either killing them or their prey. An indirect threat in Europe comes from habitat destruction by: intensified agriculture in the lowlands and the overgrowth of foreststeppe localities by forest and shrub vegetation in montane and sub-montane areas (Nagy et al., 1984; Fontana \& Cussigh, 1996; Willemse, 1996).

The aim of this work is to study the survival strategies of $S$. pedo - an endangered large predatory insect, in order to improve its conservation. Its current status at the northern boundary of its distribution area in Europe, habitat patterns and abundance, assemblages of Orthoptera and Mantodea (potential prey) in S. pedo habitats and the phenology of these assemblages are analysed. Furthermore, the morphology and growth of individuals at the periphery and localities in the centre of its distribution are compared. A preliminary study of food composition was also made. Finally, the possibilities of actively protecting and managing $S$. pedo habitats are discussed. 


\section{MATERIAL AND METHODS}

In Slovakia, between May and October 1995-2006, 418 localities in 175 mapping squares of the Databank of the Slovak fauna (40\% of Slovak squares) were checked. In 2003-2006, 36 known and potentially favourable localities were selected and visited. The minimum area of each locality was 2 ha. The number of checks per year was 2-6, each check was done between 11:00 am and 6:00 pm. The structure of Orthopteran assemblages (species spectrum and relative abundance, Table 1) was studied using several entomological methods (acoustical detection, individual collection and sweeping the herb and shrub layers, beating tree and shrub branches - a minimum of 500 sweeps and 50 beatings/check/locality).

Published data from other parts of the northern distribution limit in central Europe were collated with our field data (Nagy et al., 1984; Oláh, 1987; Berg \& Zuna-Kratky, 1997; Vidlička et al., 2002; Kočárek et al., 2005; Krištín et al., 2005; Krištín \& Kan̆uch, 2006). It was not possible to assess changes in the distribution of this species at the northernmost part of its range because the study localities have not been monitored regularly over a long period.

Individuals of $S$. pedo were trapped, measured and weighed directly in the field, using a digital calliper and a balance (type TANITA $1479 \mathrm{~V}$ ), and than released. The eggs were weighed using a SARTORIUS analytical balance. Only four nymphs $\left(5^{\text {th }}\right.$ instar) were taken from the field and reared individually in insectaria $(60 \times 40 \times 40 \mathrm{~cm}$, with sand at the bottom, and water supplied ad libidum) under standard laboratory conditions $\left(22-26^{\circ} \mathrm{C}\right.$, humidity $\left.60-70 \%\right)$ over a period of 82 days. The growth of these individuals was regularly recorded, as was the composition of their food and consumption. Daily five intact crickets or grasshoppers were provided per $S$. pedo at 9:00 am. In total, they were offered 16 species of Orthoptera (292 items), Mantis religiosa (one item) and twice three imagos and three larvae of Tenebrio molitor. The mean food consumption (prey items per individual) over seven days, the species composition of the food received and the percentage of the prey that was consumed were evaluated.

The following were used in the assessment of habitat quality: (1) habitat type, (2) altitude, (3) aspect or exposure, (4) slope, (5) distance from forest edge (canopy projection), (6) dominant woody plant in adjacent forest and (7) height of herb layer. The number of species of Orthoptera and Mantodea and their relative abundance were used in the analysis of the assemblage structure, and for determining the potential and known prey of S. pedo (Greathead, 1963; Kaltenbach, 1970). Five current localities (year 2005) of $S$. pedo were compared with five previously known localities (before 2002) in the Malé Karpaty and Tríbeč Mts (Table 1). For this comparison, the same methods and the same number of checks on the same days were used. Because there is no information on the presence or abundance of species of Orthoptera in former localities of $S$. pedo and the localities are independent, the species currently occurring at these localities were used for comparison. The mean relative abundances of individual species at the five current and five former $S$. pedo localities were compared. The comparison of species at sites, where $S$. pedo was absent and present, was made using the Wilcoxon Matched Pairs Test. Since S. pedo is known to be cannibalistic (Kaltenbach, 1970), it was also included on the list of potential prey. Seasonal changes in the numbers of species and their relative abundance were studied at a locality in the Tríbeč Mts (T1 in Table 1), where $S$. pedo occurred regularly, and were tested using the Kruskal Wallis Test.

\section{RESULTS AND DISCUSSION}

\section{Distribution, habitat and abundance}

At the northern boundary of its distribution in Europe, this species is found in four countries (Hungary - ca. 80, Slovakia - 20, Austria - 14 and Czech Republic - 4 localities). In Slovakia it was recorded before 2001 at 13 localities (Vidlička et al., 2002). In 2003-2006, an intensive search resulted in finding the species at seven new localities (Krištín et al., 2005; Krištín \& Kaňuch, 2006). The increase in number of known localities is, however, a result of the more intensive search and not an increase in range. In total, this species was hitherto found at 20 localities in six orographic units (Malé Karpaty Mts, Považský Inovec Mts, Tríbeč Mts, Slovenský kras Karst, Spišsko-šarišské medzihorie Basin, Vihorlat Mts). However, the occurrence at the last two localities has not been confirmed since 1870 and 1962, respectively. Regular occurrence was registered at two localities in the Malé Karpaty Mts and three in the Tríbeč Mts in Western Slovakia (Fig. 1).

This species is recorded in Slovakia in xerothermic forest steppes and limestone grikes (98\% of localities). It occurs on slopes of $10-45^{\circ}$ at altitudes of $220-585 \mathrm{~m}$ a.s.l. (mean $=433, \mathrm{n}=20$ localities), lower down than in southern parts of its distribution. In Hungary, the species has a wide altitudinal range: $210-940 \mathrm{~m}$ a.s.1., but avoids lowlands (Nagy, 1960; Kenyeres et al., 2002). Further south, e.g. in Switzerland, it occurs even higher up: 480-1680 m a.s.1., mostly 500-700 m a.s.1. (Thorens \& Nadig, 1997), in Macedonia up to $1700 \mathrm{~m}$ a.s.l. (Kaltenbach 1970). In Italy, it is found up to $950 \mathrm{~m}$ a.s.l. (Galvagni \& Prosser, 2004). However, in maritime regions of Italy and Slovenia it occurs on the seashore (Fontana \& Cussigh, 1996). The aspect of almost $90 \%$ of the Slovak localities is southwest or west slope. Most individuals $(66 \%)$ were found in grass-herb vegetation, $10-30 \mathrm{~cm}$ tall, $19 \%$ in vegetation taller than $30 \mathrm{~cm}$ and $15 \%$ in vegetation shorter than $10 \mathrm{~cm}$ or on the ground. Almost $87 \%$ of all specimens were within $10 \mathrm{~m}$ of the edge of a forest, the remainder within $10 \mathrm{~m}$ of shrubs. This species has not been found in large open areas. The dominant woody plants in the neighbouring forest stands were Quercus spp. (44\%), Fagus sylvatica (43\%), and Carpinus betulus (13\%). The vegetation of the forest steppes at most localities consisted of xerothermophilous shrubs (e.g. Prunus mahaleb, Fraxinus ornus, Cornus mas, Sorbus aria) and densely growing herbs (Stipa spp., Sedum spp., Teucrium spp., Centaurea spp., Coronilla spp., Festuca spp.). This habitat description conforms with that recorded 35 years ago by Kaltenbach (1970). He described its main habitat throughout its distribution and in Central Europe as dense herbaceous vegetation growing in xerothermic hills, which are frequently on limestone subsoils.

On most occasions, this large insect has hitherto been found mainly in small numbers, at most five individuals per check per locality (Nagy et al., 1984; Vidlička et al., 2002). The maximum number (36) of individuals found simultaneously at one locality was recorded in Austria, 
south of Vienna in 1995 (Berg \& Zuna-Kratky, 1997). An aggregation of ten females was observed at night in August 1971 in Sardinia (Fontana \& Cussigh, 1996) and 11 females in August 1964 in Lower Austria (Kaltenbach, 1970). In Slovakia, the maximum was 15 nymphs (all $6^{\text {th }}$ instar) observed in July 1953 at a locality in the Malé Karpaty Mts (Gulička, 1954). However, its occurrence was not confirmed there in 2003-2006.

In 2005, we focussed on determining the maximum density, as precisely as possible, finding maxima of 12 nymphs (of the $3^{\text {rd }}-5^{\text {th }}$ instar) $/ 1000 \mathrm{~m}^{2}$ (July 4, $510 \mathrm{~m}$ a.s.1., Malé Karpaty Mts, locality M1) and 6 nymphs (of the $6^{\text {th }}$ instar) $/ 1000 \mathrm{~m}^{2}$ (July 5, $360 \mathrm{~m}$ a.s.l., Tríbeč Mts, locality T1). To determine whether the stand density of woody plants influenced the abundance of this species, the time of the peak density (July 4, 2005), the abundance at two neighbouring localities (M1 and M2 $300 \mathrm{~m}$ apart) of similar size, but at different successional stages, were compared. One locality had an eight times greater density of woody plants and crown canopy than the other. The density of $S$. pedo in the more overgrown locality was about ten times lower. Subsequent checks made at these localities, during the bush-cricket's adult stage (August and September), recorded at most 3 females $/ 1000 \mathrm{~m}^{2}$. However, as this species is mainly active at twilight and during the night (Kaltenbach, 1970, 1990), these values may be an underestimate.

\section{Assemblages and phenology of Orthoptera in the habitats of Saga pedo}

There is only fragmented information on the food of $S$. pedo; Orthoptera and Mantodea are the main prey of this species (Werner, 1905; Jaus, 1934; Greathead, 1963; Kaltenbach, 1970; Cantrall, 1972). Thus, the most favourable habitats at the northern limit of $S$. pedo, are likely to be those where there are many species and an abundance of Orthoptera which should support an abundance of this species. In 2005, five localities were examined within the $S$. pedo present distribution, and 43 species of Orthoptera were found there (Table 1). Former $S$. pedo localities (where it was recorded before 2002) had only 37 species. The mean relative abundance of species of Orthoptera was also significantly higher in the five current localities (Wilcoxon Matched Pairs Test; $T=228.5, Z=2.439, P=$ $0.015, \mathrm{~N}=47$ species present in all current and former localities).

The most abundant and most frequent species of Orthoptera at $S$. pedo localities were the euryecous and xerothermophilous species of bush crickets Platycleis albopunctata grisea and Leptophyes albovittata, and the grasshoppers Chorthippus brunneus, Stenobothrus lineatus and Gomphocerippus rufus. At present S. pedo localities, eight species were found that did not occur at former localities (Isophya kraussii, Isophya camptoxypha, Psophus stridulus, Euchorthippus pulvinatus, Chorthippus albomarginatus, Myrmeleotettix maculatus, Stenobothrus eurasius and Stenobothrus nigromaculatus). Rare and unexpected species encountered were the submontane and montane species Psophus stridulus, Pholidoptera aptera and Isophya kraussii. An additional endangered species Stenobothrus eurasius was also found. In former localities of $S$. pedo, only two species that did not occur in the current localities were found, and these were atypical of xerothermic forest steppes (Table $1)$. It is not easy to compare the species spectra among $S$. pedo localities, because fewer species of Orthoptera do not necessarily indicate a lower habitat quality for $S$. pedo. For example, Nagy et al. (1998) recorded 36 species of Orthoptera at a Hungarian $S$. pedo locality (Tokaj) over a long period, but noted that $S$. pedo was not always present.

Orthopteran assemblages in $S$. pedo habitats show expected significant seasonal trends in numbers of species and their relative abundances (Kruskal Wallis Test; $\chi^{2}=$

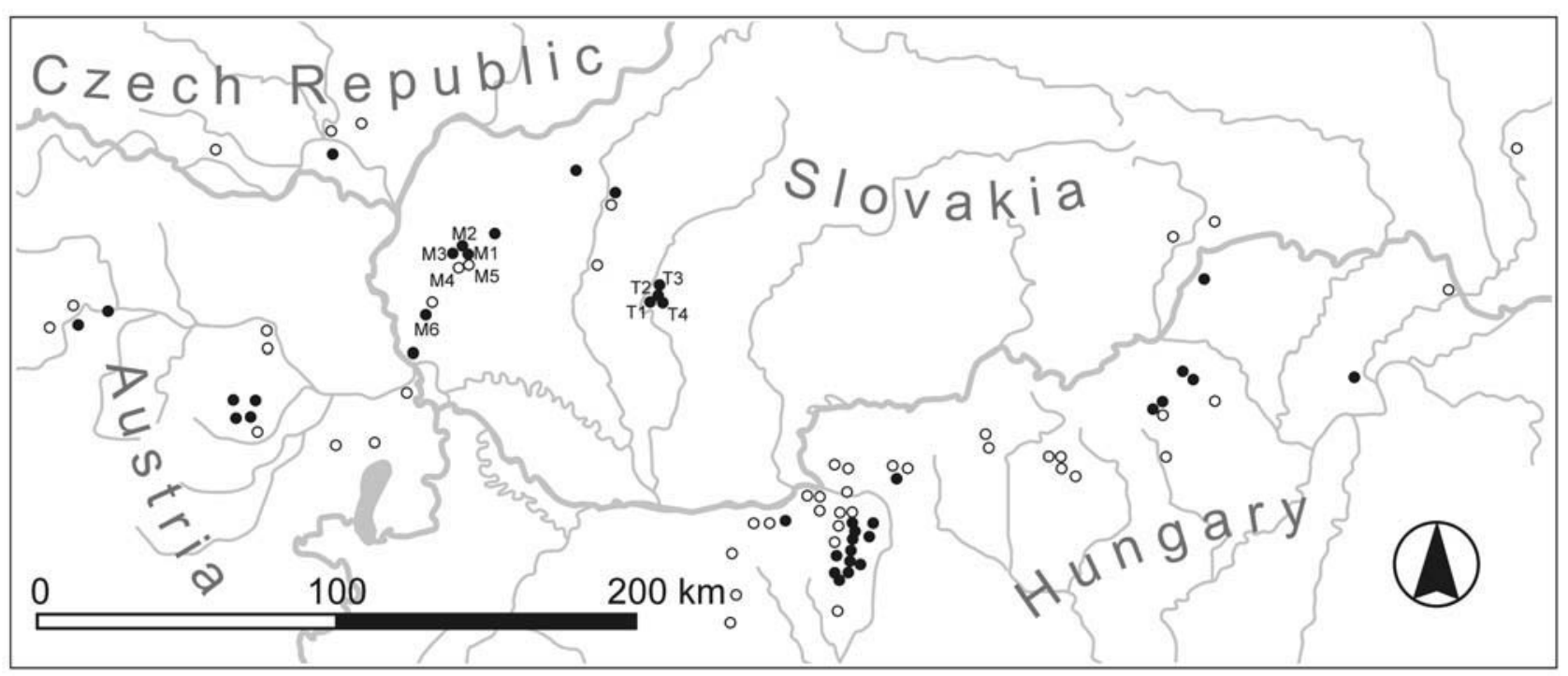

Fig.1. Distribution of Saga pedo at the northern boundary of its distribution in Central Europe (after Berg \& Zuna-Kratky, 1997; Vidlička et al., 2002; Kočárek et al., 2005 and Kenyeres et al., 2002; and including author's data) with localities studied labelled (for site labels see Table 1). Black circles - localities recorded after 1990, empty circles - localities recorded only before 1990). 
TABLE 1. Orthoptera and Mantodea assemblages in known localities for Saga pedo currently occupied (5 positive localities) or lacking (5 negative localities) this species in 2005. Relative abundance: 1 - very rare (less than 3 individuals/check), $2-$ rare (3-10 ind.), 3 - abundant (11-100 ind.), 4 - very abundant (101 and more ind.). Localities: M1-6 - Malé Karpaty Mts, T1-4 - Tríbeč Mts.

\begin{tabular}{|c|c|c|c|c|c|c|c|c|c|c|}
\hline \multirow{2}{*}{$\begin{array}{l}\text { Presence of Saga pedo } \\
\text { Locality }\end{array}$} & \multicolumn{5}{|c|}{ Positive } & \multicolumn{5}{|c|}{ Negative } \\
\hline & M1 & M2 & $\mathrm{T} 1$ & $\mathrm{~T} 2$ & $\mathrm{~T} 3$ & $\mathrm{~T} 4$ & M3 & M4 & M5 & M6 \\
\hline \multicolumn{11}{|l|}{ ORTHOPTERA } \\
\hline Calliptamus italicus (Linnaeus, 1758) & 1 & & 4 & 3 & 3 & 3 & 4 & 2 & 3 & 3 \\
\hline Chorthippus albomarginatus (Degeer, 1773) & & & 1 & 2 & 2 & & & & & \\
\hline Chorthippus apricarius (Linnaeus, 1758) & & 1 & & & 2 & & 1 & & & 2 \\
\hline Chorthippus biguttulus (Linnaeus, 1758) & 2 & 2 & 2 & 2 & 2 & 2 & 2 & & & 2 \\
\hline Chorthippus brunneus (Thunberg, 1815) & 3 & 2 & 4 & 4 & 4 & 3 & 2 & 2 & & 3 \\
\hline Chorthippus dorsatus (Zetterstedt, 1821) & & & & & & & 1 & & & \\
\hline Chorthippus mollis (Charpentier, 1825) & 2 & 1 & 2 & 3 & 3 & 2 & 1 & 1 & 1 & 1 \\
\hline Chorthippus parallelus (Zetterstedt, 1821) & 1 & 1 & & & 2 & & 2 & & & 2 \\
\hline Chorthippus vagans (Eversmann, 1848) & 1 & 1 & & & & & 1 & & & \\
\hline Chrysochraon dispar (Germar, 1834) & & & & & 2 & 1 & & & & 2 \\
\hline Conocephalus fuscus (Fabricius, 1793) & & & & & & & & & & 3 \\
\hline Decticus verrucivorus (Linnaeus, 1958) & 3 & 1 & 3 & 2 & 2 & & & 3 & & \\
\hline Ephippiger ephippiger vitium (Serville, 1831) & & & 2 & 1 & 2 & 1 & & & & \\
\hline Euchorthippus declivus (Brisout de Barneville, 1849) & & & 3 & 3 & & & & 2 & & \\
\hline Euchorthippus pulvinatus (F. de Waldheim, 1846) & & & 1 & & & & & & & \\
\hline Euthystira brachyptera (Ocskay, 1826) & 3 & 3 & 3 & 2 & 2 & 2 & 3 & 3 & 1 & 3 \\
\hline Gomphocerippus rufus (Linnaeus, 1758) & 3 & 3 & 3 & 3 & 2 & 2 & 4 & & & 3 \\
\hline Gryllotalpa gryllotalpa (Linnaeus, 1758) & & & & & & & & & & 1 \\
\hline Gryllus campestris Linnaeus, 1758 & & 2 & 3 & 3 & 3 & & 3 & 4 & 2 & 2 \\
\hline Isophya camptoxypha Fieber, 1853 & & & 2 & & & & & & & \\
\hline Isophya kraussii Brunner von Wattenwyl, 1878 & & 1 & 1 & & & & & & & \\
\hline Leptophyes albovittata (Kollar, 1833) & 3 & 3 & 4 & 3 & 3 & 2 & 4 & 3 & 3 & 3 \\
\hline Meconema thalassinum (Degeer, 1773) & & & 2 & & 1 & & & & 1 & 2 \\
\hline Metrioptera bicolor (Philippi, 1830) & 2 & & 3 & 2 & 2 & 2 & 2 & 4 & 1 & 2 \\
\hline Metrioptera roeselii (Hagenbach, 1822) & 1 & 1 & 4 & & & & 4 & 4 & 4 & 2 \\
\hline Myrmeleotettix maculatus (Thunberg, 1815) & 1 & & & & & & & & & \\
\hline Nemobius sylvestris (Bosc, 1792) & 1 & 2 & & & & & 1 & & 2 & 3 \\
\hline Oecanthus pellucens (Scopoli, 1763) & & 1 & 3 & 2 & 2 & 1 & & 2 & 2 & 2 \\
\hline Oedipoda caerulescens (Linnaeus, 1758) & 3 & 1 & 2 & 1 & 2 & 2 & 3 & 4 & 3 & 3 \\
\hline Omocestus haemorrhoidalis (Charpentier, 1825) & 2 & 2 & 3 & 3 & 3 & 2 & 3 & 2 & 2 & 2 \\
\hline Omocestus rufipes (Zetterstedt, 1821) & & & 1 & 2 & 1 & & & & & \\
\hline Phaneroptera falcata (Poda, 1761) & & & 3 & 3 & 2 & 1 & & & & 2 \\
\hline Phaneroptera nana Fieber, 1853 & & & 3 & 2 & 2 & & & & & 1 \\
\hline Pholidoptera aptera Mařan, 1953 & & 2 & & & & & 1 & 1 & & \\
\hline Pholidoptera griseoaptera (Degeer, 1773) & 4 & 3 & 3 & 1 & 2 & 2 & 4 & 2 & 4 & 2 \\
\hline Platycleis albopunctata grisea (Fabricius, 1781) & 4 & 3 & 4 & 4 & 4 & 3 & 4 & 2 & 3 & 3 \\
\hline Psophus stridulus (Linnaeus, 1758) & 2 & & & & & & & & & \\
\hline Saga pedo (Pallas, 1771) & 3 & 2 & 2 & 1 & 1 & & & & & \\
\hline Stenobothrus crassipes (Charpentier, 1825) & & & 4 & 4 & 3 & 2 & & & & \\
\hline Stenobothrus eurasius slovacus Mařan, 1958 & & & 2 & & & & & & & \\
\hline Stenobothrus lineatus (Panzer, 1796) & 4 & 3 & 4 & 4 & 3 & 1 & 4 & 4 & 4 & 2 \\
\hline Stenobothrus nigromaculatus (Herrich-Schaffer, 1840) & & & 3 & 3 & 2 & & & & & \\
\hline Tetrix bipunctata (Linnaeus, 1758) & & 1 & & & 2 & 1 & 1 & & & \\
\hline Tetrix subulata (Linnaeus, 1758) & & & 1 & & & & & & & 1 \\
\hline Tetrix tenuicornis Sahlberg, 1893 & & 1 & & & 1 & & 1 & 1 & & \\
\hline Tettigonia cantans (Fussli, 1775) & 2 & & & & & & 1 & & & \\
\hline Tettigonia viridissima Linnaeus, 1758 & 2 & 2 & 3 & 2 & 1 & & 4 & 4 & 4 & 2 \\
\hline Total number of species & 23 & 25 & 33 & 26 & 31 & 19 & 25 & 19 & 16 & 27 \\
\hline MANTODEA & & & & & & & & & & \\
\hline Mantis religiosa (Linnaeus, 1758) & 3 & 3 & 3 & 3 & 3 & 1 & 2 & 2 & 3 & 2 \\
\hline
\end{tabular}




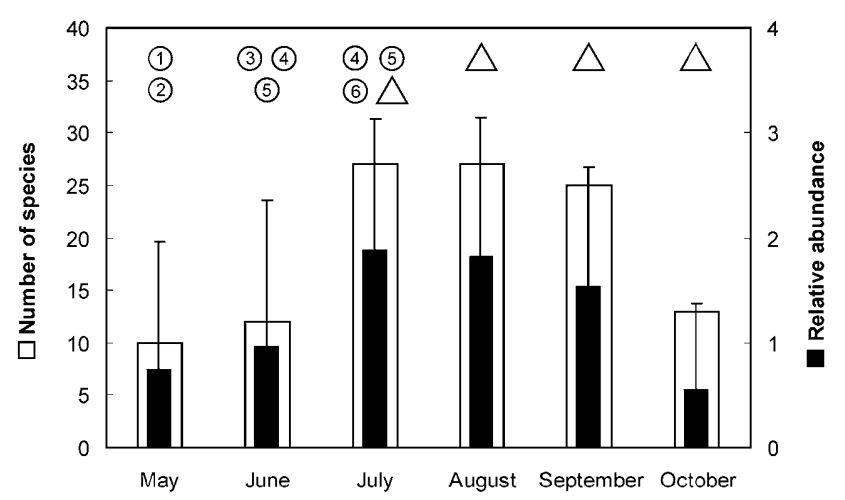

Fig. 2. Seasonal changes in number of species and relative abundance (Mean $\pm \mathrm{SD}$; values see in Table 1) of Orthoptera in habitats of Saga pedo in Tríbeč Mts in 2005 (symbols above columns indicate stage in $S$. pedo life cycle: circle - nymphal stages with instar number, triangle - adult).

39.175, df $=5, P<0.001, \mathrm{~N}=37$ ). The highest number of species (imagos) and abundances were found in July and August (Fig. 2). At this time, S. pedo is mature and developing eggs, and consumes large numbers of prey (Kaltenbach, 1970). A considerable decline in abundance was recorded in October, when $S$. pedo occurred only very rarely at localities on its northern boundary (Nagy, 1960).

\section{Morphology, growth and development of individual stages}

There is a positive correlation between increasing latitude and colder climates and body size (Bergmann's rule) in homoiothermic, but particularly in poikilothermic animals (Blackburn et al., 1999). Loder (1997) reviewed and tested the evidence for Bergmann's rule operating in the orthopteran species in Britain and found more negative than positive relationships. Hence, the expectation was that individuals of $S$. pedo developing in the suboptimal conditions at the northern boundary of the species' distribution would be smaller and lighter compared to those from the Mediterranean area. However, we discovered that individuals of $S$. pedo of different ages $(\mathrm{N}=19)$ were similar in size to the average values for the whole area. For example, the body length range of adults of 55-65 $\mathrm{mm}$ included most of ( $72 \%$ of all specimens) the measurements cited in Kaltenbach (1967) of which the ovipositor length was 31-41 mm (Kaltenbach, 1967; Harz, 1969). The individuals from the northern boundary in Slovakia consistently had these values (Table 2), which are similar to the values recorded by Schall (2002) for larvae and adults in France. Hence, there is apparently no geographic gradient in body size, but this hypothesis needs to be tested against more data.

In the laboratory (in the absence of predation and unfavourable environmental factors) the durations of the $5^{\text {th }}$ and $6^{\text {th }}$ instars and the imago $\left(7^{\text {th }}\right.$ instar) of four individuals were measured. The $5^{\text {th }}$ and $6^{\text {th }}$ instars, each lasted for 14-16 days, which is similar to the findings of Schall (2002), but 4-7 days longer than those cited by Sänger (1980) for Saga natoliae at significantly higher temperatures $\left(34-36^{\circ} \mathrm{C}\right)$. Healthy adults survived in an insectary for a maximum of 59 days, which is much shorter than the 89-144 days mentioned by Schall (2002) or 117 days cited for S. natoliae (Kaltenbach, 1970). Using the duration of development of the individual instars (Schall, 2002), the total potential age of our reared individuals was calculated to be around 130 days (at $22-26^{\circ} \mathrm{C}$ ), which is significantly shorter than the 159-226 days, cited by Schall (2002) for captive individuals from southern France.

In the localities studied in 2005, the nymphs hatched from eggs from May 1-12, moulted from the $5^{\text {th }}$ to $6^{\text {th }}$ instar from July 12-14, the last moults were recorded from July 22-28, and the last imagos were found in the field on October 6.

The eggs of this species are amongst the largest known for insects, being on average $11.9 \mathrm{~mm}$ long, by $3.8 \mathrm{~mm}$ wide and weighting $41 \mathrm{mg}(\mathrm{N}=4)$. Hence, the length and width are larger by $1 \mathrm{~mm}$ than those of the congeneric species Saga hellenica (Vrabec \& Kočárek, 2005), 2 mm longer than those of $S$. pedo in Austria and $2.1 \mathrm{~mm}$ longer than those of $S$. natoliae and $0.7 \mathrm{~mm}$ shorter than those of Saga ephippigera (Sänger \& Helfert, 1994).

\section{Food composition and consumption}

Of the single mantid ( $M$. religiosa), single beetle species (T. molitor) and 16 orthopteran species offered to four individuals of $S$. pedo, a total of 12 orthopteran species and the mantid were avidly consumed. Over $60 \%$ of the prey offered were totally consumed. The prey species were: Chorthippus parallelus, C. apricarius, C. brunneus, C. dorsatus, C. albomarginatus, C. biguttulus, Stenobothrus lineatus, Euthystira brachyptera, Chrysochraon dispar, Oedipoda caerulescens, Metrioptera roeselii, M. bicolor and M. religiosa. For a long period (a minimum of 10 days) the following prey species were not attacked and eaten: Tettigonia viridissima, L. albovittata, Decticus

TABLE 2. Some morphological parameters and weight (Mean $\pm \mathrm{SD}$ ) of the $3^{\text {rd }}-6^{\text {th }}$ instars and imago of Saga pedo.

\begin{tabular}{|c|c|c|c|c|c|c|c|}
\hline \multirow{2}{*}{ Stage of development } & \multirow{2}{*}{$\mathrm{n}$} & \multicolumn{5}{|c|}{ Length (mm) } & \multirow{2}{*}{$\begin{array}{c}\text { Weight } \\
\text { (g) }\end{array}$} \\
\hline & & Body & Ovipositor & Antenna & Hind tibia & Total size & \\
\hline $3^{\text {rd }}$ instar (18 June) & 2 & $25.1 \pm 1.4$ & $3.5 \pm 0.1$ & $26.2 \pm 0.5$ & $16.6 \pm 0.2$ & $54.8 \pm 2.1$ & $0.3 \pm 0.1$ \\
\hline $4^{\text {th }}$ instar (18 June, July 4 ) & 2 & $27.8 \pm 0.3$ & $7.4 \pm 0.4$ & $25.3 \pm 10.3$ & $16.7 \pm 3.3$ & $60.4 \pm 10.9$ & $0.5 \pm 0.1$ \\
\hline $5^{\text {th }}$ instar (July 5) & 5 & $39.3 \pm 1.0$ & $15.4 \pm 1.2$ & $40.6 \pm 1.7$ & $27.6 \pm 1.8$ & $95.3 \pm 3.9$ & $0.8 \pm 0.1$ \\
\hline $6^{\text {th }}$ instar (July 20) & 7 & $47.7 \pm 3.1$ & $31.8 \pm 0.8$ & $48.2 \pm 2.0$ & $34.7 \pm 1.6$ & $127.8 \pm 5.9$ & $1.7 \pm 0.3$ \\
\hline Imago, fresh (July 22) & 1 & 58.1 & 34.7 & 55.9 & 40.4 & 148.7 & 1.5 \\
\hline Imago, with eggs (Sep. 6) & 3 & $59.9 \pm 0.3$ & $34.5 \pm 2.1$ & $59.9 \pm 1.9$ & $43.2 \pm 2.1$ & $154.3 \pm 4.3$ & $3.1 \pm 0.6$ \\
\hline
\end{tabular}


verrucivorus, Phaneroptera falcata and T. molitor (no $T$. molitor were attacked even over a period of 82 days). Kaltenbach (1970) mentions they feed on bush-crickets, which were not offered in our experiments, and emphasized the importance of a daily supply of active grasshoppers as the main prey. Individual $S$. pedo $\left(5^{\text {th }}-7^{\text {th }}\right.$ instar $)$ consumed an average of 10-11 Orthoptera (of the size of $C$. parallelus or $S$. lineatus) every seven days. Maximum daily consumption of $S$. pedo was three adults of $C$. parallelus during its last larval instar and first four weeks post adult moult, which accords with the findings of Kaltenbach (1970). For comparison, Cantrall (1972) found a much higher consumption rate for a single specimen of $S$. pedo (up to six grasshoppers, Melanoplus sanquinipes, daily).

\section{Proposals for species and habitat conservation}

Based on the analyses of current and former habitats and the assemblages of Orthoptera around $S$. pedo, it is concluded that the principal threats are: successional overgrowth of localities by vegetation and afforestation. Other supposed threats are intensive land-use for recreation and illegal collecting. Because this species is critically endangered in Europe, it is necessary to include it not only in Annex IV, but also in Annex II of the Council Directive 92/43/EEC of 21 May 1992 on the conservation of natural habitats and of wild fauna and flora. This extremely big insect is an ideal "flagship" species, the protection of which requires the declaration of protected areas (see also Nagy et al., 1984; Willemse, 1996; Berg \& Zuna-Kratky, 1997).

To ensure this species' survival, it is essential to stop successional changes in vegetation and afforestation in the species' localities by introducing traditional management and farming (extensive grazing by goats and sheep), mowing (in autumn) and removal of woody plants and seedlings. Restoration of populations in previously inhabited localities, which are still suitable (using introductions of populations from adjacent localities where the species is relatively abundant), may be successfull by simultaneous protecting $S$. pedo from predation and unfavourable climate (Schall, 2002). Regular mapping of suitable localities is essential, as is the proper protection and monitoring of the abundance of local populations, especially during the nymphal stages (May-July).

ACKNOWLEDGEMENTS. For help with the field work we would like to acknowledge P. Puchala (Administration of PLA Malé Karpaty), L. Strasser and T. Hahner (University of Freising). For inspiration and comments we thank also three anonymous referees. The work was supported by VEGA grants No. $2 / 6007 / 06$ and 2/5152/05. M. Blair and D. Kúdelová are acknowledged for their help with the preparation of the English text.

\section{REFERENCES}

Berg H.-M. \& Zuna-KratKy T. 1997: Heuschrecken und Fangschrecken. Eine Rote Liste der in der Niederösterreich gefährdeten Arten. NÖ Landesregierung, Wien, 112 pp.
Blackburn T.M., Gaston K.J. \& Loder N. 1999: Geographic gradients in body size: a clarification of Bergmann's rule. Divers. Distrib. 5: 165-174.

Cantrall I. J. 1972: Saga pedo (Pallas) (Tettigoniidae: Saginae) an old world katydid new to Michigan. Gt. Lakes Entomol. 5: 103-106.

Fontana P. \& Cussigh F. 1996: Saga pedo (Pallas) ed Empusa fasciata Brulle in Italia, specie rare da proteggere. Atti Acc. Rov. Agiati 246(6): 47-64.

Galvagni A. \& Prosser F. 2004: Saga pedo (Pallas, 1771) found in Trentino, North Italy. Atti. Acc. Rov. Agiati 254(4): 97-106.

GREATHEAD D.J. 1963: A review of the insect enemies of Acridoidea (Orthoptera). Trans. R. Entomol. Soc. London 114: 437-517.

GULIČKA J. 1954: Beitrag zur Kenntnis der Verbreitung einiger Orthopteren und Dermapteren in der Slowakei. Biológia (Bratislava) 9: 617-630 [in Slovak, German abstr.].

Harz K. 1969: Die Orthopteren Europas. Vol. I. Dr. W. Junk, The Hague, 749 pp.

Ingrisch S. \& KöHLER G. 1998: Die Heuschrecken Mitteleuropas. Die Neue Brehm Bücherei 629. Westarp Wissenschaften, Magdeburg, $460 \mathrm{pp}$.

Heller K.-G. 2004: Fauna Europaea: Ensifera, Caelifera. Fauna Europaea version 1.1, http://www.faunaeur.org.

Heller K.-G., Korsunoviskaya O., Ragge D.R., Vedenina V., Willemse F., Zhantiev R.D., \& Frantsevich L. 1998: Checklist of European Orthoptera. Articulata 7: 1-61.

JAUS I. 1934: Ein Beitrag zur Biologie von Saga serrata F. Konowia (Wien) 13: 171-177.

Kaltenbach A. 1967: Unterlagen für eine Monographie der Saginae 1. Superrevision der Gattung Saga Charpentier (Saltatoria: Tettigoniidae). Beitr. Entomol. (Berlin) 17: 3-107.

Kaltenbach A. 1970: Unterlagen für eine Monographie der Saginae II. Beiträge zur Autökologie der Gattung Saga Charpentier (Saltatoria: Tettigoniidae). Zool. Beitr. 16: 155-245.

Kaltenbach A.P. 1990: The predatory Saginae. In Bailey W.J. \& Rentz D.C.F. (eds): The Tettigoniidae. Biology, Systematics and Evolution. Springer, Berlin, pp. 280-302.

Kenyeres Z., Bauer N. \& RÁcz I. 2002: Saga pedo Pallas dans le bassin des Carpates, synthèse et nouvelles données (Orthoptera, Tettigoniidae). Bull. Soc. Entomol. Fr. 107: 149-156.

KočÁReK P., HoluŠA J. \& VidLIČKa L. 2005: Blattaria, Mantodea, Orthoptera \& Dermaptera of the Czech and Slovak Republics. Kabourek, Zlín, 348 pp.

KRIŠTín A. 2001: Red list of Orthoptera of Slovakia. Ochrana Prírody (Suppl.) 20: 103-104 [in Slovak, English abstr.].

KRIŠTín A. \& KaŇUCH P. 2006: Grasshoppers and crickets (Orthoptera) and mantids (Mantodea) of the Zoborské vrchy Mts. area (W Slovakia). Rosalia 18: 99-108 [in Slovak, English abstr.].

KRIŠTín A., KañuCh P. \& Puchala P. 2005: Orthopteroid insects (Orthoptera s. 1.) of the Malé Karpaty Mts. (W Slovakia). Ochrana Prírody 24: 56-66 [in Slovak, English abstr.].

Loder N. 1997: Insect Species Body Size Distributions. Ph.D. Thesis, University of Sheffield.

NAGY B. 1960: Vertikale Grenzen des Vorkommens der Sägeschrecke (Saga pedo Pall.) in Ungarn. Fol. Entomol. Hungar. (N.S.) 13: 251-252 [in Hungarian, German abstr.].

Nagy B., Kis B. \& Nagy L. 1984: Saga pedo Pall. (Orthoptera, Tettigoniidae): Verbreitung und ökologische Regelmässigkeiten des Vorkommens in SO-Mitteleuropa. Verh. SIEEC X, Budapest 1983: 190-192.

NAGY B., ŠušLíK V. \& KRIŠTín A. 1998: Distribution of Orthoptera species and structure of assemblages along Slanské - 
Zemplén Mountains Range (SE Slovakia - NE Hungary). Folia Entomol. Hung. 59: 17-27.

OlÁH M. 1987: A new occurrence of the Saw-legged grasshopper, Saga pedo (Pall.) in the Mátra Mts. Fol. Hist. Nat. Mus. Matr. 12: 43-45.

SäNGER K. 1980: Zur Larvalentwicklung der LaubheuschreckenArt Saga natoliae (Orthoptera: Tettigonioidea). Entomol. Gener. 6: 65-69.

SÄNGer K. \& Helfert B. 1994: Vergleich von Anzahl und Lage der Mikropylen und der Form der Eier von Saga pedo, S. natoliae und S. ephippigera (Orthoptera: Tettigoniidae). Entomol. Gener. 19: 49-56.

Schall A. 2002: Details on the knowledge of Saga pedo (Pallas, 1771), biological cycle in captivity (Orthoptera, Tettigoniidae, Saginae). Bull. Soc. Entomol. Fr. 107: 157-164.

Thorens P. \& Nadig A. 1997: Atlas de Distribution des Orthoptères de Suisse. Documenta Faunistica Helvetiae 16 , CSCF, Neuchâtel, 236 pp.
ViddičKa L., JanskÝ V., Fedor P.J., Krumpál M. \& LuKáš J. 2002: Distribution of Saga pedo in Slovakia. Articulata 17: 95-100.

VRABeC V. \& KoČÁReK P. 2005: The observation of Saga hellenica Kaltenbach, 1967 (Orthoptera) on Korfu Island. Entomofauna Carpath. 17: 11-13.

WerNer F. 1905: Die Verbreitung und Lebensweise der Riesenheuschrecken aus der Gattung Saga, insbesondere in Europa. Mitt. Nat. Ver. Univ. Wien 3(1): 1-4.

WILLEMSE L. 1996: Saga pedo. In Helsdingen P.J. van, Willemse L. \& Speight M.C.D. (eds): Background Information on Invertebrates of the Habitats Directive and the Bern Convention. Part 2. - Mantodea, Odonata, Orthoptera and Arachnida. Nature and Environment Series 80. Council of Europe Publ., Strasbourg, pp. 383-393.

Received April 6, 2006; revised and accepted September 1, 2006 